\title{
Pediatric infections
}

\author{
CHAIRPERSON \\ NONI E MACDONALD, MD, FRCPC
}

A LONG WITH THE TASK OF ASSESSING THE NEED, INTEREST, and format for a multicentre Pediatric Infectious Diseases Clinical Studies Network, the pediatric infection workshop focused on three clinical problems.

- Respiratory syncytial virus (RSV) infection in compromised hosts.

- Pediatric human immunodeficiency virus (HIV) infections.

- Condylomata acuminata in children.

\section{RSV IN COMPROMISED HOSTS}

Since RSV was first recovered from patients in 1957. it has emerged as the most frequent cause of acute lower respiratory tract infection in infants and young children (1-3). Infection severe enough to require hospitalization occurs primarily in infants younger than 12 months (4). However, during the past decade, a number of researchers have recognized that infants and children with certain underlying conditions such as congenital heart disease, bronchopulmonary dysplasia, cystic fibrosis, certain congenital anomalies or immunocompromised status are at increased risk for more severe disease (5-9). Simultaneous infection with other respiratory pathogens such as adenovirus also appears to have a devastating effect (10).

The precise pathophysiology of more severe disease in these special groups of patients remains to be deter-

Workshop participants: W Abelson, G Ahronheim, $R$ Bortolussi, F Boucher, S Halperin, S King, RB Larke, B Law, $V$ Marchessault, E Mills, L Navas, H Onyett, R Peeling. $R$ Pennie, D Scheifele, D Speert, E Wang

Correspondence: Dr NE MacDonald, Head, Division of Infectious Disease, Children's Hospital of Eastern Ontario, 401 Smyth Road, Ottawa, Ontario K1H 8L1. Telephone (613) $737-7600$ mined as does optimal management. The evidence that ribavirin makes a clinically important difference in these special patients is limited but suggestive $(11,12)$. However, due to the very small numbers of patients studied and limited stratification for severity of disease it is unclear if ribavirin is helpful (13). Furthermore, an anecdotal report suggests that ribavirin therapy may be detrimental (14).

The initial RSV study proposed by the workshop group is to survey all tertiary care pediatric centres in Canada to determine:

- the number of infants and children hospitalized with RSV per year during the past three years;

- the number admitted to intensive care units and the number who required assisted ventilation;

- the patient characteristics of those admitted to the intensive care units, their mortality rate;

- duration of hospitalization, supplemental oxygen requirements and assisted ventilation; and

- frequency and duration of current ribavirin use. Dr Elaine Wang (Hospital for Sick Children in Toronto, Ontario) will develop the questionnaire and be the coordinator for the study. The collected data will be used to develop a multicentre stratified randomized controlled evaluation of various treatment options for these high risk patients.

\section{PEDIATRIC HIV INFECTION}

During the past decade, perinatally acquired HIV infection has emerged as a serious problem in many parts of the world. Two recent reports suggest that perinatal HIV infection may result in two very different clinical patterns in terms of rapidity of onset of serious complications and long term survival $(15,16)$. Scott and colleagues (15) in an analysis of the clinical course of 
HIV infection in 172 children from Miami, Florida with perinatally acquired HIV infection, noted that early age at diagnosis and the first identifiable pattern of clinical disease were found to be independently related to survival. Blanche and co-workers (16) in France extended this observation by noting a bimodal survival distribution in 94 patients with perinatally acquired HIV. Approximately one-third of their patients had early onset of opportunistic infection and these infants were more likely to have severe encephalopathy compared to infants without early opportunistic infections. Survival at three years for the group with early symptoms was $48 \pm 24 \%$ compared to $97 \pm 3 \%$ for those without early opportunistic infections or severe encephalopathy.

The initial HIV study proposed by the workshop group is to survey the burden and pattern of HIV illness in children in Canada through tertiary care pediatric centres across the country. A questionnaire and protocol will be developed by Dr Susan King (Hospital for Sick Children, Toronto) and Dr Ross Pennie (Children's Hospital of Eastern Ontario, Ottawa, Ontario) to try to answer the following questions:

- what factors influence the pattern of perinatally acquired HIV?

- when is zidovudine being started?

- is immunization beneficial in early life (less than 15 months), and/or in later life (after immune deficiency is apparent); and

- does intravenous gammaglobulin benefit all children with HIV or only a subset?

\section{CONDYLOMATA ACUMINATA IN CHILDREN}

Condylomata acuminata or venereal warts are variably sized papillomatous growths predominantly confined to the anogenital region and are caused by human papillomavirus (HPV). Analysis of disease in adults has shown HPV types 6 and 11 to be the most common but types 16 and 18 also occur and have been associated with cervical neoplasia, vulvar and vaginal in situ and invasive carcinomas, and penile and perianal cancers (18). Limited data are available concerning HPV types in pediatric condylomata cases but types 6 , 11,16 and 18 have been identified (19,20). The long term sequelae and oncogenic potential of these infections in children and adolescents are unknown. A

\section{REFERENCES}

1. Chanock R, Finberg L. Recovery from infants with respiratory illness of a virus related to chimpanzee coryza agent (CCA). II. Epidemiologic aspects of infection in infants and young children. Am J Hyg 1957;66:291-300.

2. Glezen WP, Denny FW. Epidemiology of acute lower respiratory disease in children. $\mathrm{N}$ Engl $\mathrm{J}$ Med 1973;288:498-505.

3. Kim WH, Arrobio JO, Brandt CD, et al. Epidemiology of respiratory syncytial virus infection in Washington. I. Importance of the virus in different respiratory tract disease syndromes and temporal distribution of infection. Am J Epidemiol 1973:98:216-25. recent review by Boyd (21) of the 83 pediatric cases in the English literature suggests that the anatomic distribution in children differs from that in adults. Male children have much more perianal disease and less penile disease compared to adults. Analysis of the female disease pattens shows fewer age related differences, but labial disease is higher in adult women. However, these anatomic distribution patterns of the condylomata are different from those reported in the study of 73 children reported by Cohen et al (20).

Transmission in children is thought to occur primarily by one of three major mechanisms:

- from an infected birth canal at the time of delivery;

- routine nonsexual family contact; and

- by sexual contact.

In Boyd's review 28\% of the 83 cases were thought to be due to sexual abuse but $37 \%$ were unknown (21). In Cohen's study of 73 cases, $11 \%$ were thought to be due to abuse (20). When one remembers the very different distribution in male children versus adults, one has to be suspicious that many more cases may also be due to abuse.

The optimal treatment regimen for children is unknown. As in adults, cryotherapy, surgery and electrofulguration and laser therapy have been used with variable results (21). No systematic pediatric trials with stratification for extent of disease and random allocation to treatment type have been carried out.

The initial condylomata study proposed by the workshop group is to survey all tertiary care pediatric centres in Canada to determine:

- the number of genital HPV-infected children seen in each institution in the previous two years and to collect demographic, clinical presentation,

treatment and follow-up data on these patients; and

- to carry out long term follow-up of the patients seen in these centres from 1980-85.

Dr Noni MacDonald (Children's Hospital of Eastern Ontario, Ottawa) and Dr Joanne Embree (Winnipeg Health Sciences Centre, Winnipeg, Manitoba) will develop the questionnaire. This information will then be used to develop a prospective study to determine HPV type as it relates to the mode of transmission, relapse rate with therapy and long term sequelae.

4. Parrott RH, Kim HW, Arrobio JO, et al. Epidemiology of respiratory syncytial virus infection in Washington. II. Infection and disease with respect to age, immunologic status, race, and sex. Am J Epidemiol 1973:98:289-300.

5. MacDonald NE, Hall CB, Suffin SC, et al. Respiratory syncytial viral infection with congenital heart disease. N Engl J Med 1982;307:397-400.

6. Groothuis JR, Gutierrez KM, Lauer BA. Respiratory syncytial virus infection in children with bronchopulmonary dysplasia. Pediatrics 1988;82:199-203.

7. Abman SH, Ogle JW, Butler-Simon N, et al. Role of respiratory syncytial virus in early hospitalizations for 
respiratory distress of young infants with cystic fibrosis. J Pediatr 1988; 113:826-30.

8. Grootbuis JR, Salbenblatt CK, Lauer BA. Severe respiratory syncytial virus infection in older children. Am J Dis Child 1990;144:346-8.

9. Hall CB, Powell KR, MacDonald NE, et al. Respiratory syncytial viral infection in children with compromised immune function. N Engl J Med 1986;315:77-81.

10. Tristram DA, Miller RW, McMillan JA, Weiner LB. Simultaneous infection with respiratory syncytial virus and other respiratory pathogens. Am J Dis Child 1988;142:834-6.

11. Hall CB, McBride JT, Gala CL, et al. Ribavirin aerosol treatment of bronchiolitis associated with respiratory syncytial virus infection in children with underlying cardiopulmonary disease. J Am Med Assoc 1985:254:3047-51.

12. Groothius JR, Woodin KA, Katz R, et al. Early ribavirin treatment of respiratory syncytial virus infection in high risk children. J Pediatr 1990;117:792-8.

13. Wald ER, Dashefsky B, Green M. In re ribavirin: A case of premature adjudication? J Pediatr 1988:112:154-8.
14. Eisenberg $\mathrm{J}$. Hemodynamic alterations in patients treated with ribavirin. Pediatr Infect Dis J 1990;9:S93-4.

15. Scott GB, Hutto C, Makuch RW, et al. Survival in children with perinatally acquired human immunodeficiency virus type 1 infection. N Engl J Med 1989;321:1791-6.

16. Blanche S, Tardieu M, Duliege A-M, et al. Longitudinal study of 94 symptomatic infants with perinatally acquired human immunodeficiency virus infection. Am J Dis Child 1990;144:1210-5.

17. Gissmann L, Boshart M, Durst M, et al. Presence of human papillomavirus in genital tumors. J Invest Dermatol 1984;83(Suppl 1):26-8.

18. WHO. Genital human papillomavirus infections and cancer: Memorandum from a WHO meeting. Bull WHO 1987;65:817-27.

19. Rock B, Naghashfar Z, Barnett N, et al. Genital tract papillomavirus infection in children. Arch Dermatol 1986;122:1129-32.

20. Cohen BA, Honig P, Androphy E. Anogenital warts in children. Arch Dermatol 1990;126:1575-80.

21. Boyd AS. Condylomata acuminata in the pediatric population. Am J Dis Child 1990; 144:817-24. 


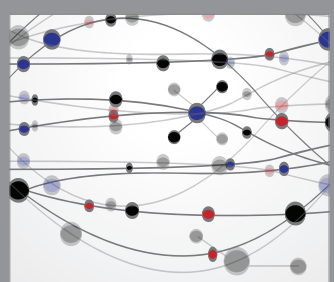

The Scientific World Journal
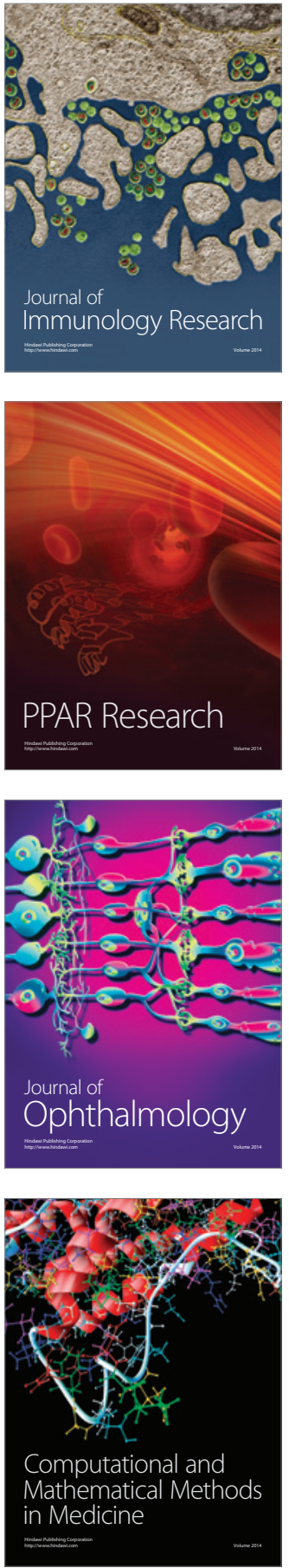

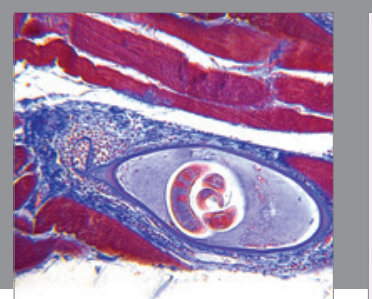

Gastroenterology Research and Practice

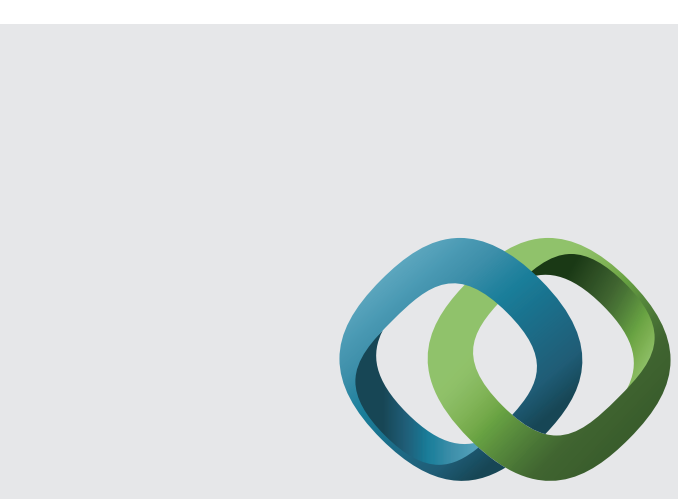

\section{Hindawi}

Submit your manuscripts at

http://www.hindawi.com
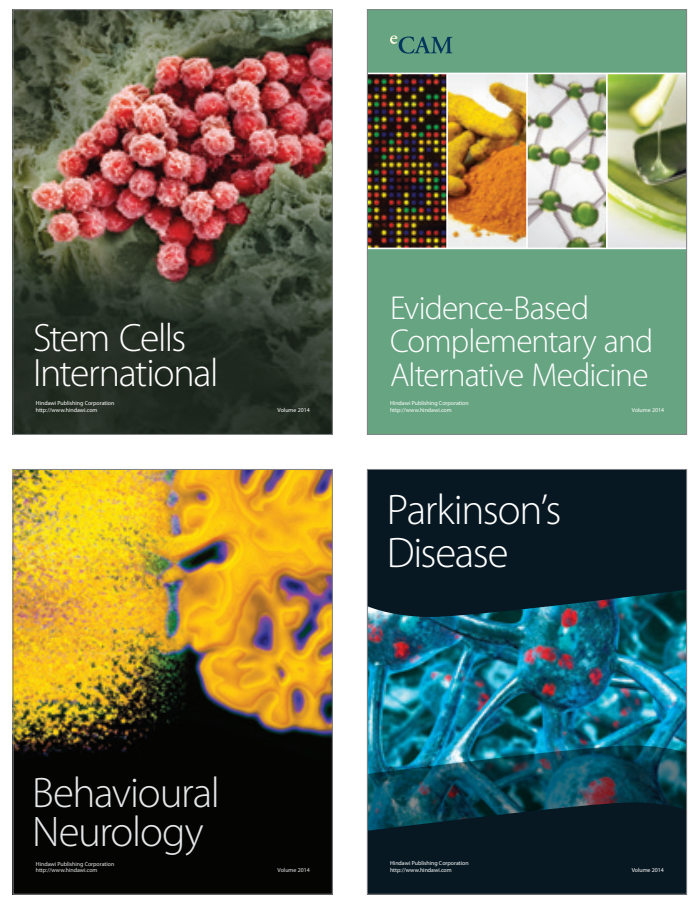
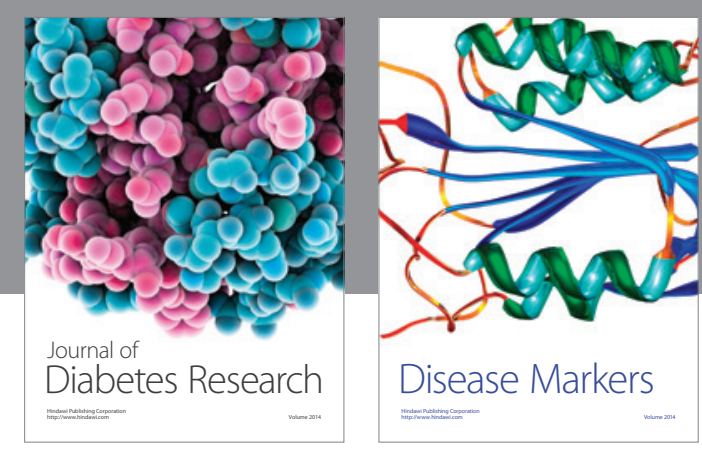

Disease Markers
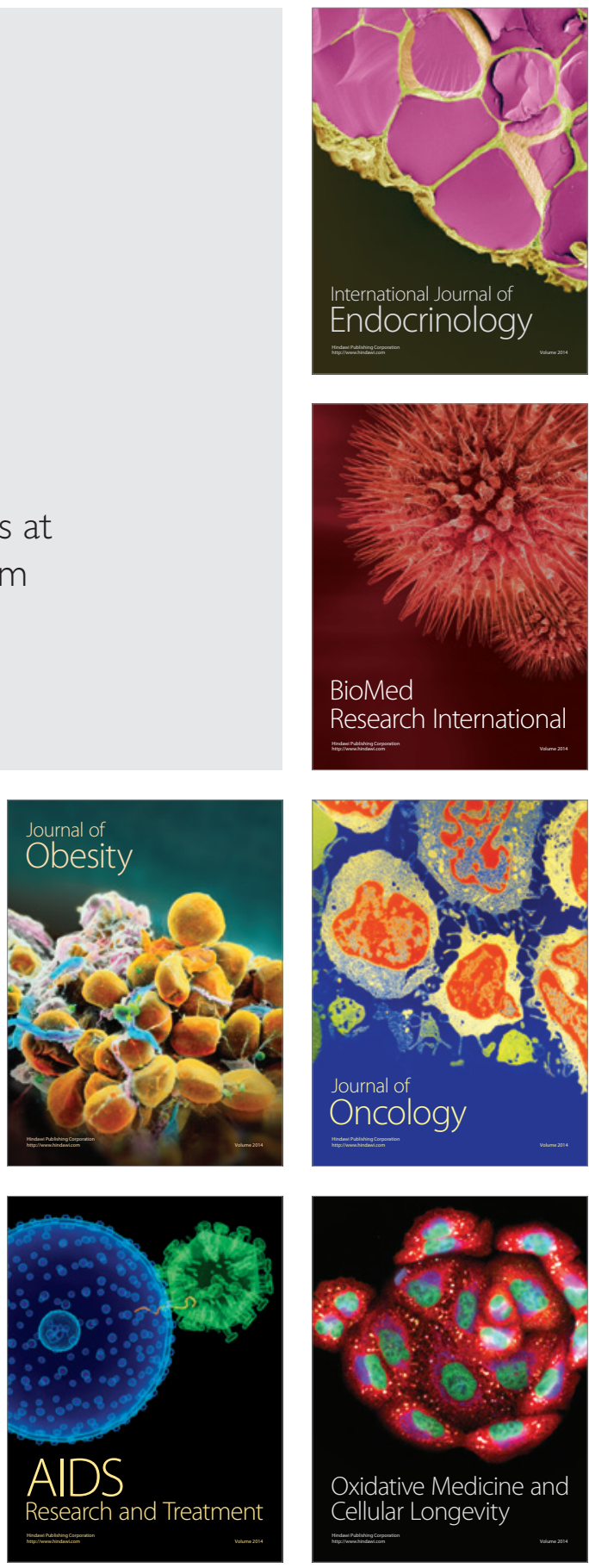